\title{
Combined Detection of Serum Heat Shock Protein-90 $\alpha$ and Prostate Specific Antigen for Prostate Cancer Diagnosis
}

\author{
Shichang Zhang1, Jiang Zheng2* \\ ${ }^{1}$ Yangtze University, Jingzhou, China \\ ${ }^{2}$ Jingzhou First People's Hospital, Jingzhou, China \\ Email: ^1213472862@qq.com
}

How to cite this paper: Zhang, S.C. and Zheng, J. (2020) Combined Detection of Serum Heat Shock Protein-90 $\alpha$ and Prostate Specific Antigen for Prostate Cancer Diagnosis. Yangtze Medicine, 4, 284-292. https://doi.org/10.4236/ym.2020.44026

Received: December 20, 2019

Accepted: September 27, 2020

Published: September 30, 2020

Copyright $\odot 2020$ by author(s) and Scientific Research Publishing Inc. This work is licensed under the Creative Commons Attribution International License (CC BY 4.0).

http://creativecommons.org/licenses/by/4.0/ (c) (i) Open Access

\begin{abstract}
Objective: To explore the relationship between heat shock protein-90 $\alpha$ (HSP-90 $\alpha$ ) and occurrence of prostate cancer, and clinical value of combined detection of serum HSP-90 $\alpha$ and prostate specific antigen (PSA) in the diagnosis of prostate cancer. Method: A total of 30 patients with prostate cancer, 30 patients with benign prostatic hyperplasia (BPH) and 30 healthy men (control group) were selected from September 2018 to September 2019, then to detect levels of serum HSP-90 $\alpha$, total PSA and free PSA (FPSA) by ELISA, serum testosterone level by radioimmunoassay, prostate cancer tissue was removed by operation, and relative expression of tissue HSP-90 $\alpha$ protein by Western blot. Results: The levels of serum HSP-90 $\alpha$ and total PSA in prostate cancer group were significantly higher than other two groups, and testosterone level was lower than other two groups $(\mathrm{P}<0.05)$; there was no difference of serum FPSA level between the three groups $(\mathrm{P}>0.05)$. It was found by Pearson test that serum HSP-90 $\alpha$ was positively correlated with total PSA level $(r=0.659, P=0.005)$, while negatively correlated with testosterone level ( $r$ $=-0.549, \mathrm{P}=0.006)$. According to TNM stage of prostate cancer, there were 17 cases of stage I - II, 13 cases of stage III - IV, 6 cases of Gleason score 1 - 4, 13 cases of $5-7,11$ cases of $8-10$, tumor diameter range from 0.8 to $6.2 \mathrm{~cm}$, with average of $(3.9 \pm 1.5) \mathrm{cm}$. The relative expression of HSP-90 $\alpha$ protein in tumor tissue was closely related to TNM stage, Gleason score and tumor diameter $(\mathrm{P}<0.05)$. By ROC analysis, it was found that accuracy of combined detection of serum HSP-90 $\alpha$ and PSA levels for prostate cancer diagnosis was 0.896, and that of single PSA detection was 0.852. Conclusion: Higher expressions of HSP-90 $\alpha$ in prostate cancer tissue and serum may be closely related to occurrence and development of prostate cancer, and combined detections of serum HSP-90 $\alpha$ and PSA levels are of great significance in improving early diagnosis of prostate cancer.
\end{abstract}




\section{Keywords}

Heat Shock Protein-90 $\alpha$, Prostate Specific Antigen, Prostate Cancer

\section{Introduction}

Prostate cancer is the second most common malignant tumor in men, with a rapid increase in recent years, increasing with age [1]. The diagnosis and TNM staging of Prostate cancer are mainly based on prostate specific antigen (PSA) level, MRI, biopsy of Prostate biopsy, and isotopic bone scan, etc., which are the main basis for the diagnosis and treatment of Prostate cancer clinically [2]. China's PSA screening is not yet complete, at least $35.8 \%$ of prostate cancer patients have advanced to advanced prostate cancer when diagnosed [3]. With the in-depth study on the molecular mechanism of tumor development, it has been found that Heat shock protein-90 (HSP-90) may be activated through multiple signaling pathways in the process of prostate cancer carcinogenesis, which is closely related to the occurrence, development, treatment and prognosis of prostate cancer [4] [5]. This study mainly discussed the relationship between HSP-90 and the incidence of prostate cancer, and the clinical value of combined detection of serum HSP-90 and PSA in the diagnosis of prostate cancer.

\section{Objects and Methods}

\subsection{Object Data}

A total of 30 patients with pathologically diagnosed prostate cancer, 30 with benign prostatic hyperplasia (BPH) and 30 healthy males (control group) were randomly selected from September 2018 to September 2019. Inclusion criteria: 1) Age 18 - 75; 2) Consistent with the diagnosis of prostate cancer and BPH [6] [7]; 3) Prostate cancer and BPH without surgery, chemoradiotherapy or biological therapy; 4) Obtain informed consent and ethics medicine of our college, the clinical data completed. Exclusion criteria: 1) Kidney tumors, urinary tract infections, and stones; 2) Severe liver and kidney dysfunction and autoimmune diseases.

Patients with prostate cancer ranged in age from 48 to 74 years, with an average age of $56.5 \pm 9.7$ years, body mass index (BMI) $23.5-27.8 \mathrm{~kg} / \mathrm{m}^{2}$, mean $(25.5$ $\pm 2.6) \mathrm{kg} / \mathrm{m}^{2}$. There were 17 cases of stage I - II and 13 cases of stage III - IV in TNM stage. Gleason scores ranged from 1 to 4 in 6,5 to 7 in 13, and 8 to 10 in 11. Tumor diameter ranged from 0.8 to $6.2 \mathrm{~cm}$, with an average $(3.9 \pm 1.5) \mathrm{cm}$. Patients with BPH ranged in age from 45 to 73 years, with an average age of $(56.3 \pm 9.5)$ years. BMI $23.3-27.5 \mathrm{~kg} / \mathrm{m}^{2}$, mean $(25.2 \pm 2.5) \mathrm{kg} / \mathrm{m}^{2}$; The control group was $44-75$ years old, with an average of $(56.6 \pm 9.9)$ years old, and a BMI of $23.2-27.9 \mathrm{~kg} / \mathrm{m}^{2}$, with an average of $(25.6 \pm 2.8) \mathrm{kg} / \mathrm{m}^{2}$. The age and BMI of the three groups were comparable $(\mathrm{P}>0.05)$. 


\subsection{Research Methods}

Serum HSP-90, total PSA and free PSA (FPSA) levels were detected by ELISA, serum testosterone levels were detected by radioimmunoassay, prostate cancer tissues were surgically removed, and the relative expression of HSP-90 protein in tumor tissues was detected by Western blot. The normal reference range of serum HSP-90 was $0-82 \mathrm{ng} / \mathrm{ml}$. The normal PSA reference range is $0-4 \mathrm{ng} / \mathrm{ml}$, the FPSA reference range is $1-1.2 \mathrm{ng} / \mathrm{ml}$, and the testosterone reference range is $300-1000 \mathrm{ng} / \mathrm{dl}$ for men.

\subsection{Detection Method}

\subsubsection{Main Steps of ELISA}

Fasting cubical vein $6 \mathrm{ml}$ was collected in edta-k2, mixed upside down for 6 - 8 times, and the upper layer of plasma was absorbed into another EP tube. Adjust the microplate analyzer, open the microplate analyzer software, set the plate layout, including 6 calibration holes, 1 - 2 quality control holes and sample holes; The kit was taken out and balanced at $37^{\circ} \mathrm{C}$ for $30 \mathrm{~min}$. The freeze-preserved samples were melted at room temperature and thoroughly mixed, and diluted 20 times (5 1 sample +951 diluent). Adding samples, adding 501 calibration products, quality control products and diluted samples to the plate hole continuously and without interruption according to the sequence of hole layout of the enzyme marker, the whole plate was completed within $10 \mathrm{~min}$. Add markers, add 501 marker liquid to each plate hole, cover the sealing plate film and slightly mix; After incubation, the solid plate was incubated at $37^{\circ} \mathrm{C}$ for $60 \mathrm{~min}$. Wash the plate in the plate washer, add $50 \mathrm{l}$ chromogenic agent $\mathrm{A}$ and $\mathrm{B}$ into the plate hole, cover the sealing plate film and slightly mix; The solid plate was incubated at $37^{\circ} \mathrm{C}$ for $20 \mathrm{~min}$. Add $50 \mathrm{l}$ stop fluid to the plate hole, slightly mix; The solid phase plate was placed into the microplate to read OD value within $10 \mathrm{~min}$ at $560 \mathrm{~nm}$ wavelength. The normal reference range of serum HSP-90 was $0-82$ $\mathrm{ng} / \mathrm{ml}[8]$. The normal PSA reference range is $0-4 \mathrm{ng} / \mathrm{ml}$, the FPSA reference range is $1-1.2 \mathrm{ng} / \mathrm{ml}$, and the testosterone reference range is $300-1000 \mathrm{ng} / \mathrm{dl}$ for men [9].

\subsubsection{Main Steps of Western Blot}

The freshly resected tumor tissue was then ultrasonically crushed, and RIPA lysate was added to fully lyse the cells and release the protein. BCA protein quantitative reagent (Sigma) was used to extract the cell protein and test the concentration and purity. Groups were $30 \mathrm{mu}$ of g protein samples, $8 \%$ sds-page electrophoresis separation, the separation zone electric transferred to the PVDF membrane, increase the mouse anti human HSP-90 alpha and internal beta actin antibodies to a resistance (dilute the concentration of 1:2000, the sigma company) stand for the night, PBS washing resistance drops plus rabbit to sustain rat corresponding antibody two (1:500, the sigma company) at room temperature, 4 $\mathrm{h}$ incubation, PBS washing, ECL color. Results: Lab Works 4.5 gel imaging software (Invitrogen, USA) was used for semi-quantitative analysis, and the gray 
scale ratio of HSP-90 tablets and gam-actin protein electrophoresis strip was used for expression [10].

\subsection{Statistical Methods}

SPSS20.0 software was used for statistical analysis, the measurement data were expressed as mean \pm standard deviation, single factor ANOVA analysis was used for comparison between the three groups, lsd-t test was used for pairwise comparison, $t$ test was used for comparison between the two groups, Pearson test was used for correlation analysis, and the counting data were expressed as cases (\%), and the comparison was performed by 2 test. The serum PSA or combined HSP-90 and PSA levels were used as the indicators for the diagnosis of prostate cancer. The accuracy (expressed by the AUC value of the area under the curve), sensitivity and specificity of the diagnosis were analyzed by ROC, and the critical value was obtained. $\mathrm{P}<0.05$ was considered statistically significant.

\section{Results}

\subsection{Comparison of Serum HSP-90, PSA and Testosterone Levels between Groups}

Serum HSP-90 and total PSA levels in the prostate cancer group were significantly higher than those in the other two groups, and testosterone levels were lower than those in the other two groups $(\mathrm{P}<0.05)$. There was no difference in serum FPSA levels among the three groups $(\mathrm{P}>0.05)$, as shown in Table 1.

\subsection{Correlation Analysis}

Pearson's test showed that serum HSP-90 was positively correlated with total PSA, while negatively correlated with testosterone $(\mathrm{P}<0.05)$, as shown in Table 2.

Table 1. Comparison of serum HSP-90, PSA and testosterone levels between groups.

\begin{tabular}{cccccc}
\hline Group & Cases & $\begin{array}{c}\text { HSP-90 } \alpha \\
(\mathrm{ng} / \mathrm{ml})\end{array}$ & $\begin{array}{c}\text { TPSA } \\
(\mathrm{ng} / \mathrm{ml})\end{array}$ & $\begin{array}{c}\text { FPSA } \\
(\mathrm{ng} / \mathrm{ml})\end{array}$ & $\begin{array}{c}\text { Testosterone } \\
(\mathrm{ng} / \mathrm{dl})\end{array}$ \\
\hline Prostate cancer & 30 & $105.9 \pm 23.5$ & $5.9 \pm 1.5$ & $1.3 \pm 0.6$ & $426.5 \pm 65.9$ \\
Prostatic hyperplasia & 30 & $38.4 \pm 8.9$ & $2.5 \pm 0.8$ & $1.2 \pm 0.5$ & $756.5 \pm 123.9$ \\
Control group & 30 & $35.6 \pm 7.7$ & $2.3 \pm 0.6$ & $1.1 \pm 0.3$ & $762.9 \pm 154.8$ \\
F & & 32.635 & 5.326 & 0.352 & 65.639 \\
P & 0.000 & 0.002 & 0.428 & 0.000 \\
\hline
\end{tabular}

Table 2. Correlation analysis.

\begin{tabular}{cccc}
\hline & TPSA & FPSA & Testosterone \\
\hline HSP-90 $\alpha$ & $\mathrm{R}=0.659, \mathrm{P}=0.005$ & $\mathrm{R}=0.523, \mathrm{P}=0.248$ & $\mathrm{R}=-0.549, \mathrm{P}=0.006$ \\
Testosterone & $\mathrm{R}=0.632, \mathrm{P}=0.421$ & $\mathrm{R}=0.529, \mathrm{P}=0.632$ & - \\
\hline
\end{tabular}




\subsection{Relationship between HSP-90 Protein Expression in Prostate Cancer Patients and Tumor}

The relative expression level of HSP-90 in tumor tissues was closely related to TNM stage, Gleason score and tumor diameter $(\mathrm{P}<0.05)$, as shown in Table 3 and Figure 1.

\subsection{ROC Analysis}

ROC analysis showed that the accuracy of the combined detection of serum HSP-90 and PSA level in the diagnosis of prostate cancer was 0.896 , while the accuracy of the separate detection of PSA was 0.852 , as shown in Table 4 and Figure 2.

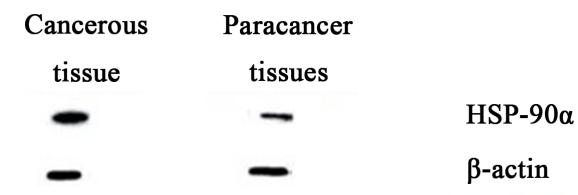

Figure 1. The relative expression level of HSP-90 protein in prostate cancer and adjacent tissues was detected by Western blot (the relative expression level of HSP-90 protein in cancer tissues was significantly higher than that in adjacent normal tissues $(\mathrm{P}<0.05)$.

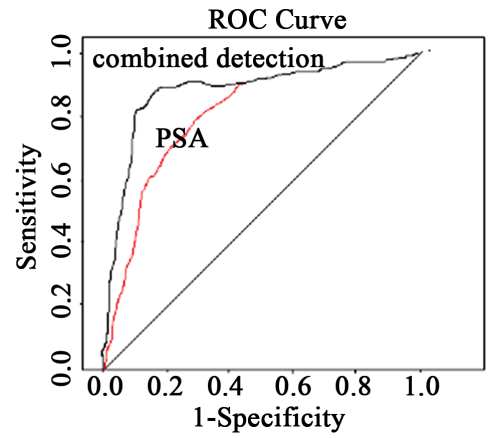

Figure 2. ROC analysis was performed for the diagnosis of prostate cancer by combining serum HSP-90 and PSA levels with a separate PSA test.

Table 3. Relationship between HSP-90 protein expression in prostate cancer patients and tumor.

\begin{tabular}{ccccc}
\hline & Cases & HSP-90 $\alpha$ & T or F & P \\
\hline TNM staging & & & 5.006 & 0.006 \\
I - II & 17 & $0.36 \pm 0.07$ & & \\
III - IV & 13 & $0.45 \pm 0.09$ & & 0.000 \\
Gleason score & & & 8.326 & \\
$1-4$ & 6 & $0.31 \pm 0.05$ & & \\
$5-7$ & 13 & $0.41 \pm 0.06$ & & \\
$8-10$ & 11 & $0.49 \pm 0.08$ & & \\
Tumor diameter $(\mathrm{cm})$ & & & 5.231 & \\
$<3.9$ & 14 & $0.35 \pm 0.06$ & & \\
$\geq 3.9$ & 16 & $0.42 \pm 0.08$ & & \\
\hline
\end{tabular}


Table 4. ROC analysis.

\begin{tabular}{ccccc}
\hline indicators & AUC value & Sensitivity & Specificity & The critical value \\
\hline PSA & 0.852 & $86.7 \%$ & $80.5 \%$ & $\begin{array}{c}3.2 \mathrm{ng} / \mathrm{ml} \\
\text { PSA }=3.0 \mathrm{ng} / \mathrm{ml}, \\
\text { The joint detection }\end{array}$ \\
& 0.896 & $90.6 \%$ & $86.5 \%$ & $\mathrm{HSP}-90 \alpha=68.9 \mathrm{ng} / \mathrm{ml}$ \\
\hline
\end{tabular}

\section{Discussion}

HSP is a group of highly conserved proteins commonly found in eukaryotes, which are mainly involved in protein folding, transport, activation, degradation and protein signaling as molecular chapels [11]. HSP plays an important role in promoting cell survival, maintaining cell autoimmune regulation and other defense mechanisms, and protecting cells from radiation-induced death [12]. HSP is not only expressed in normal cells, but also in some invasive tumors or metastatic cancers. In colorectal cancer, gastric cancer, cervical cancer tumor tissue detection [13] [14], tumor tissue HSP-90 alpha mRNA and protein expression of relative quantity obviously higher than that of precancerous normal tissue, cell differentiation and TNM staging of the tumor, the level, closely related to lymphatic metastasis, tumor malignant degree is higher, HSP-90 alpha positive expression rate and quantitative expression level is also higher. It is suggested that the up-regulation of HSP-90 expression is closely related to the degree of malignancy of various malignant tumors.

This study mainly discussed the pathogenesis of HSP-90 in prostate cancer. It was found that serum HSP-90 and total PSA levels in prostate cancer group were significantly higher than those in the other two groups, while testosterone levels were lower than those in the other two groups $(\mathrm{P}<0.05)$. There was no difference in serum FPSA levels among the three groups $(P>0.05)$. It is suggested that the incidence of prostate cancer may be related to the increased release of HSP-90 and PSA, and the decreased secretion of testosterone. Tumor cells affected by the changes of external environment in the body, such as inflammatory factor, the inductive effect protein combined with molecular chaperone and release heat shock factor (heat shock factor, (HSF) expression of HSP-90 alpha expression is regulated by the HSF, HSF forming complexes with HSP-90 alpha in inactivation state, stress complex dissociation, HSF into the nucleus, start the heat shock protein gene and protein transcription process [15] [16]. HSP-90 can prevent protein aggregation, promote the folding of the initial polypeptide chain, and participate in the refolding of damaged proteins and the isolation of degraded damaged proteins [17]. HSP-90 can also reduce cell apoptosis and regulate immune response, thus increasing cell viability [18].

Pearson test found that serum HSP-90 was positively correlated with total PSA level, while negatively correlated with testosterone level $(\mathrm{P}<0.05)$. Furthermore, the relative expression of HSP-90 protein in tumor tissues was closely related to TNM stage, Gleason score and tumor diameter $(\mathrm{P}<0.05)$. It is suggested that the malignancy of prostate cancer is closely related to the increased 
expression of HSP-90 protein. The main function of HSP-90 is to maintain the stability of cell proteins, improve the tolerance of cells to stress response, and make cells maintain normal physiological functions. The content of HSP-90 in tumor cells is 2 - 10 times that of normal cells, and its substrate proteins include a variety of key signaling molecules for tumor growth and metastasis, and HSP-90 is present in a high activity state in a variety of malignant tumor cells [19] [20]. ROC analysis showed that the accuracy of the combined detection of serum HSP-90 and PSA level in the diagnosis of prostate cancer was 0.896 , while the accuracy of the separate detection of PSA was 0.852 .

PSA as a screening and diagnosis of prostate diseases has a good sensitivity, but the detection level is susceptible to a variety of factors, and the accuracy needs to be improved [21]. High expression of HSP-90 in prostate cancer may be due to rapid growth of cancer tissues, nutrient deficiency and chronic hypoxia, which stimulates increased transcription synthesis of HSP-90 in prostate cancer cells, and sustained high induction of expression. At the same time, the self-protection ability of cancer tissues is enhanced to improve the survival ability of cancer cells [22] [23] [24].

\section{Conclusion}

In conclusion, the increased expression of HSP-90 in prostate cancer tissues and serum may be closely related to the occurrence and development of the tumor, and the combined detection of serum HSP-90 and PSA levels is of great significance to improve the early diagnosis of prostate cancer. Due to the limited sample size, this study did not dynamically analyze the changes of serum HSP-90 serum level in prostate cancer patients before and after treatment, and failed to elaborate the relationship between HSP-90 serum, PSA and testosterone changes; and cell pathway HSP-90 serum affects the occurrence and development of prostate cancer.

\section{Conflicts of Interest}

The authors declare no conflicts of interest regarding the publication of this paper.

\section{References}

[1] Siegel, R.L., Miller, K.D. and Jemal, A. (2018) Cancer Statistics. CA: A Cancer Journal for Clinicians, 68, 7-30. https://doi.org/10.3322/caac.21442

[2] Carroll, P.H. and Mohler, J.L. (2018) NCCN Guidelines Updates: Prostate Cancer and Prostate Cancer Early Detection. Journal of the National Comprehensive Cancer Network, 16, 620-623. https://doi.org/10.6004/jnccn.2018.0036

[3] Wu, Q.H. and Yao, X.P. (2018) Treatment Progress of High-Risk Prostate Cancer. Modern Practical Medicine, 30, 1263-1265.

[4] Lu, C., Lu, Z.X. and Bai, Z.P. (2016) Expression and Significance of Heat Shock Protein 90 and Glycoprotein 96 in Human Prostate Cancer. Journal of Modern Urology, 21, 226-230. 
[5] Cheng, M.N., Xu, J.H., Zhao, J.M., et al. (2015) Advances in Heat Shock Protein 90 and Tumor. Journal of Yan' an University (Medical Science Edition), 13, 62-64.

[6] Sanda, M.G., Cadeddu, J.A., Kirkby, E., et al. (2018) Clinically Localized Prostate Cancer: AUA/ASTRO/SUO Guideline. Part I: Risk Stratification, Shared Decision Making, and Care Options. The Journal of Urology, 199, 683-690.

https://doi.org/10.1016/j.juro.2017.11.095

[7] Foster, H.E., Barry, M.J., Dahm, P., et al. (2018) Surgical Management of Lower Urinary Tract Symptoms Attributed to Benign Prostatic Hyperplasia: AUA Guideline. The Journal of Urology, 200, 612-619. https://doi.org/10.1016/j.juro.2018.05.048

[8] Lamoureux, F., Thomas, C., Yin, M.J., et al. (2014) Suppression of Heat Shock Protein 27 Using OGX-427 Induces Endoplasmic Reticulum Stress and Potentiates Heat Shock Protein 90 Inhibitors to Delay Castrate-Resistant Prostate Cancer. European Urology, 66, 145-155. https://doi.org/10.1016/j.eururo.2013.12.019

[9] Gao, Y., Zhang, M., Li, X., et al. (2019) Serum PSA Levels in Patients with Prostate Cancer and Other 33 Different Types of Diseases. Progress in Molecular Biology and Translational Science, 162, 377-390. https://doi.org/10.1016/bs.pmbts.2018.12.013

[10] Lee, M.G., Liu, Y.C., Lee, Y.L., et al. (2018) Heteronemin, a Marine Sesterterpenoid-Type Metabolite, Induces Apoptosis in Prostate LNcap Cells via Oxidative and ER Stress Combined with the Inhibition of Topoisomerase II and HSP90. Marine Drugs, 16, 154-155. https://doi.org/10.3390/md16060204

[11] Fang, C.L., Lu, Y.C., Fu, Q.X., et al. (2019) Advances in the Correlation between Heat Shock Protein 90 and Tumor. Hainan Medical Science, 30, 1744-1747.

[12] Chen, H., Tu, Y.L., Pan, W., et al. (2019) Clinical Value of Heat Shock Protein $90 \alpha$ in Tumor Diagnosis and Treatment. Shanghai Medical, 40, 51-52, 64.

[13] Long, J., Li, Q., Zheng, Q., et al. (2019) Research Progress of Heat Shock Protein 90 $\alpha$ in Tumor. Clinical study in China, 32, 421-423.

[14] Wang, W. and Liu, X.Y. (2019) Changes of Serum Pepsin and Heat Shock Protein 70 Levels in Patients with Duodenal Tumor Resection during Perioperative Period and Their Clinical Significance. Chinese Journal of Modern Medicine, 29, 77-82.

[15] Dai, C. and Sampson, S.B. (2016) HSF1: Guardian of Proteostasis in Cancer. Trends in Cell Biology, 26, 17-28. https://doi.org/10.1016/j.tcb.2015.10.011

[16] Wu, W., Liu, F.F., Liu, Y., et al. (2016) The Role of Targeted HSF1 in Tumor Therapy. Journal of Medical Molecular Biology, 13, 52-58.

[17] Liu, T. and Zhang, Z. (2018) Advances in Heat Shock Protein and Nasopharyngeal Carcinoma. Journal of Yan' an University (Medical Science Edition), 16, 84-86, 90.

[18] He, X.H., Dong, H.M. and Cai, S.X. (2017) Advances in Extracellular Heat Shock Protein 90 as a Tumor Marker. Journal of Practical Medicine, 33, 1523-1525.

[19] Qiao, D.D. and Luo, L. (2016) Biological Characteristics of Heat Shock Protein 90 and Tumor. Yunnan Medicine, 37, 676-679.

[20] Shi, S.S., Guo, H.L., Pang, H., et al. (2016) Effects of Dendritic Cells and Cytokine-Induced Killer Cells Loaded with Heat Shock Protein 96 on Homologous Tumor Stem Cells. Chinese Journal of Modern Medicine, 18, 10-14.

[21] Huang, G.H. and Li, W. (2019) Application and Progress of Prostate-Specific Antigen (PSA) Related Parameters in Prostatic Puncture. Journal of Modern Urology, 24, 72-76. 
[22] Suzuki, R., Hidehsima, T., Mimura, N., et al. (2015) Antitumor Activities of Selective HSP $90 \alpha / \beta$ Inhibitor, TAS-116, in Combination with Bortezomib in Multiple Myeloma. Leukemia, 29, 510-514. https://doi.org/10.1038/leu.2014.300

[23] Wang, Y.J., Qi, X., Dai, J.J., et al. (2017) Effects of HSP 90 and Its Inhibitors on Tumor Immune Response. Advances in Modern Biomedicine, 17, 3790-3794.

[24] Faridi, U., Dhawan, S.S., Pal, S., et al. (2016) Repurposing L-Menthol for Systems Medicine and Cancer Therapeutics L-Menthol Induces Apoptosis through Caspase 10 and by Suppressing HSP 90. OMICS, 20, 53-64.

https://doi.org/10.1089/omi.2015.0118 